\title{
Antibiotics in Leprosy, with Special Reference to Rifampicin
}

\author{
D. V. A. OPROMOLLA AND C. J. S. TONELLO \\ Hospital Airmores, Rodovia Bauru-Jau, km 385, Caixa Postal 62, \\ Bauru - E.S. Paulo, Brazil
}

\begin{abstract}
The authors record the results obtained with various antibiotics, in particular the rifamycins, in the treatment of leprosy.

Improvement was most obvious and rapid in those patients whose disease was getting worse, and in whom bacterioscopy showed morphologically typical solid and long bacilli.

They analyse the results obtained with rifampicin in daily doses of 600 to $900 \mathrm{mg}$ observed for varying lengths of time. They conclude that rifampicin should not be used alone. In cases resistant to other drugs, former treatment should be maintained in conjunction with the antibiotic until the reactivation is controlled. In patients who have had no previous treatment the antibiotic could be given in addition to sulphones, but not for longer than 120 days.
\end{abstract}

We have tested several antibiotics in leprosy treatment, including cycloserine, oxytetracycline, doxycycline, kanamycin and several rifamycins (See Table 1). The clinical results were uniformly good during an observation period of 12 months. In the majority of these drugs, maximum therapeutic effects were noted within the first 4 months, after which improvement was slower. The best results were obtained in patients who were experiencing a worsening of their disease. There were no differences in the incidence of ENL. During the period of observation no patients got worse.

In spite of the fact that according to some authors oxytetracycline does not exhibit anti-leprotic activity, and Shepard and Godal were unable to observe that it occasioned any inhibition in the growth of bacilli in the mouse footpad, the clinical and bacteriological results in our patients were good, and some of them could be called excellent. We agree with Weinstein (1967) when he affirms, "The only expressive indication of therapeutic effect is a favourable clinical response" (referring to the lack of correlation between the concentration of sulphonamides in the blood and the therapeutic effects observed). The bacteriological results follow the same pattern of response as that seen with the other antibiotics studied. Thus the Bacteriological Indices did not change much after a year's observation, and the Morphological Indices showed a clear predominance of degenerate bacilli at the end of this time.

The rifamycins acted similarly to the other antibiotics studied. The excellent response observed with rifamycin SV given intramuscularly, mainly to patients who were obviously getting worse, made Souza Lima and ourselves conclude in 1963 that, "The result of these experiments, in some ways surprisingly favourable if we consider the relatively short period of experimentation, opens up new roads in the field of therapeutic investigations of leprosy". 


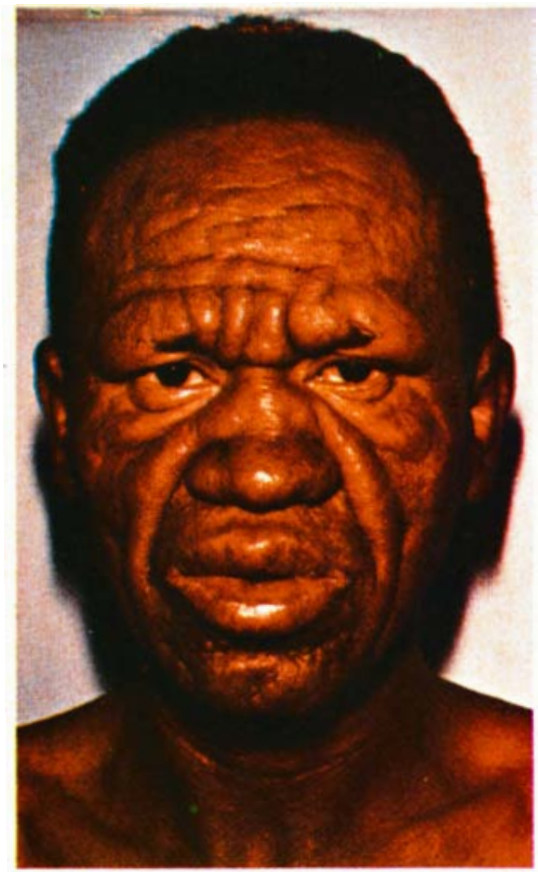

Fig. 1. Before treatment.

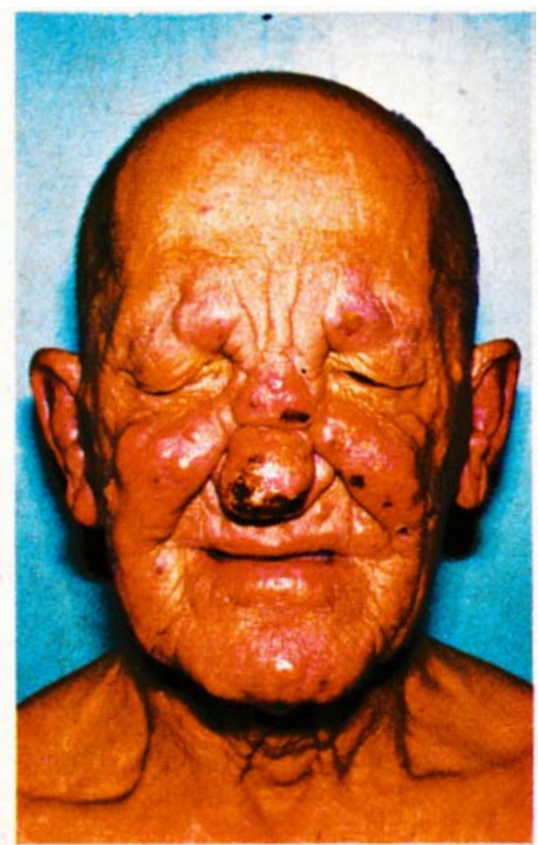

Fig. 3. Before treatment.

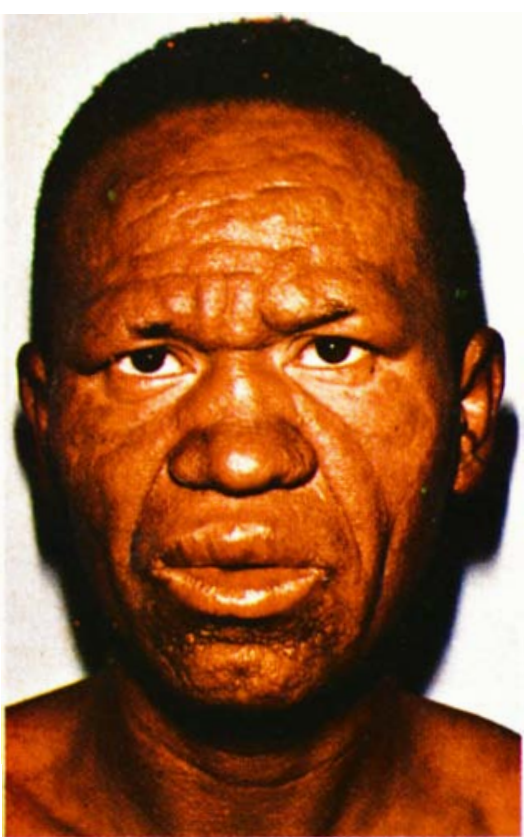

Fig. 2. After 20 days of treatment.

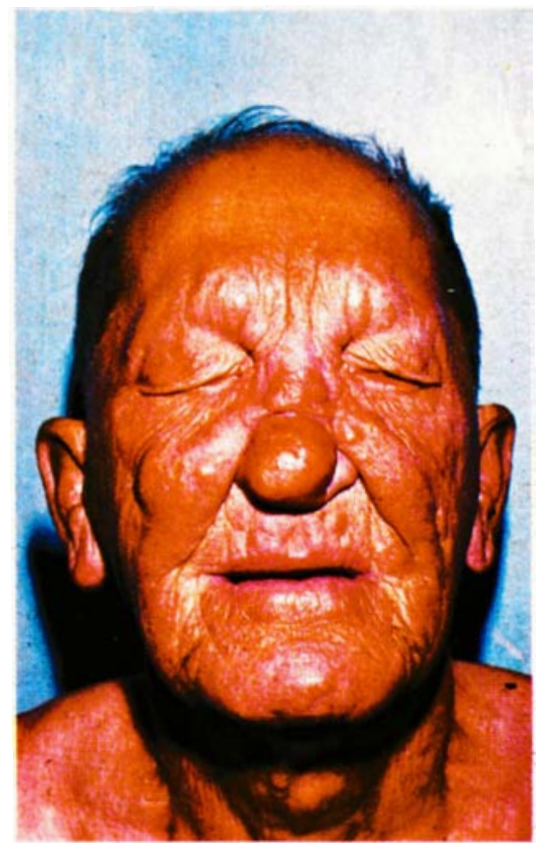

- Fig. 4. After 30 days of treatment. 
Rifampycin SV given intravenously confirmed these findings of high activity; in spite of the small number of cases studied, convincing clinical responses were observed within short periods of treatment (see Figs 1 and 2). The bacteriological status after one year of treatment with this antibiotic showed the same pattern as that of the others.

We conclude, therefore, that the antibiotics, particularly the rifamycins, are active in patients whose disease is worsening, and where solid staining and long bacilli predominate. We also conclude that maximum activity is observed in the first 4 months of treatment.

TABLE 1

\begin{tabular}{lcccc}
\hline \multicolumn{1}{c}{ Antibiotic } & $\begin{array}{c}\text { Daily } \\
\text { dosage }\end{array}$ & $\begin{array}{c}\text { Route of } \\
\text { administration }\end{array}$ & $\begin{array}{c}\text { Number of } \\
\text { patients }\end{array}$ & $\begin{array}{c}\text { Duration of } \\
\text { treatment (months) }\end{array}$ \\
\hline Cycloserine + INH & $1.0 \mathrm{~g}$ & oral & 32 & 12 \\
Rifamycin SV & $1.0 \mathrm{~g}$ & IM & 10 & 12 \\
Rifamycin SV & $1.0 \mathrm{~g}$ & IV & 5 & 12 \\
Rifamycin SV + & $1.0 \mathrm{~g}$ & IV & & 12 \\
DDS + & $100 \mathrm{mg}$ & oral & 5 & 12 \\
Sulfadimethoxine & $500 \mathrm{mg}$ & oral & & 3 \\
Oxytetracycline & $200 \mathrm{mg}$ & IM & 22 & $4-8$ \\
Kanamycin & $1.0 \mathrm{~g}$ & IM & 10 & $1-28$ \\
Doxycycline & $100 \mathrm{mg}$ & oral & 14 & \\
Rifampicin & $600-$ & oral & 52 & \\
\hline
\end{tabular}

TABLE 2

\begin{tabular}{cc}
\hline \multicolumn{2}{c}{ Rifampicin } \\
$\begin{array}{c}\text { Duration of treatment } \\
\text { (months) }\end{array}$ & Number of patients \\
\hline $1-4$ & 18 \\
$5-8$ & 11 \\
$9-12$ & 10 \\
$13-16$ & 2 \\
$17-28$ & 12 \\
\hline
\end{tabular}

With the advent of rifampicin (derived from rifamycin SV), which is given orally, we have begun therapeutic schemes on the basis of the conclusions mentioned above. In our hospital routine, patients who do not respond to sulphones and other drugs, and whose disease is clearly degenerating, have received rifampicin in daily doses of 600 to $900 \mathrm{mg}$. At the moment 53 patients are being observed, of whom 32 have lepromatous leprosy and fulfil the above requirements. Of the remainder, 9 were receiving drugs other than sulphones, but because these drugs were no longer available, and in spite of the patients' improvement, they were given rifampicin; 6 had received no previous treatment for leprosy, and 6 with "borderline" leprosy continued to present active lesions in 
spite of long periods of treatment with sulphones and other drugs. The duration of treatment and the number of patients in each category are indicated in Table 2.

Clinically, those patients who presented with recent reactivation of old lesions or with new lesions improved rapidly, while those whose reactivation was of longer duration improved more slowly. In all the patients who had already been under treatment for 1 year, old lesions remain, improved but still active (Figs 3 and 4$)$.

The response of those patients who were improving slowly with other drugs and who began treatment with the antibiotic, continues to be favourable, but slow and less obvious.

In those patients who had received no previous treatment for leprosy, the group with a large number of lesions of short duration, most of which were in the same stage, improved rapidly, until after 4 months the lesions were no longer active. The others with lesions already dormant improved also, but more slowly.

The patients with "borderline" leprosy did not develop new lesions, and the existing lesions improved gradually. The bacteriological status in all these patients does not differ essentially from that observed with rifamycin SV, in other words Bacteriological Indices were only slightly different after 1 year of treatment, and Morphological Indices showed a predominance of degenerate bacilli.

A point worthy of note is that in patients with relapsed lepromatous leprosy who after a year still present active lesions, the Morphological Index does not return to zero as many reports indicate. A certain proportion of solid bacilli persisted in the smears.

The clinical and bacteriological findings permit us to make the following observations:

(1) The existence of resistance to rifampicin has already been described in tuberculosis, and the persistence of morphologically normal bacilli after a year of treatment suggests that resistance also occurs in leprosy.

(2) This antibiotic should not be used alone.

(3) In the cases resistant to other drugs, rifampicin should be used in conjunction with the drug in previous use until the new lesions disappear. If reactivation occurs again, the same combination of drugs should be given.

(4) In patients who have had no previous treatment for leprosy, rifampicin should be used in conjunction with sulphone for the first 4 months, after which treatment should proceed with a sulphone alone, bearing in mind the compatibility of the 2 drugs given simultaneously as demonstrated by Shepard.

(5) Rifampicin is well tolerated, but its high cost limits its use except in special cases. It should be used with caution, and with the aim of preventing the emergence of resistant strains, which would further limit its area of usefulness.

\section{References}

Languillon, J. (1971). Activité de deux antituberculeux: La rifampicine et l'ethambutol dans la maladie de Hansen. Acta Leprol. 46-47, 123-131.

Leiker, D. L. and Kamp, H. (1970). First results of treatment of leprosy with rifadin. Lepr. Rev. 41, 25-30.

Lima, L. S. and Opromolla, D. V. A. (1963). First results on the treatment of leprosy with rifamycin SV. Chemotherapia 7, 668-678.

Opromolla, D. V. A. (1963). Primeiros resultados com a "Rifamicine SV" na lepra lepromatosa. In Congresso Internacional de Leprologia, $8^{\circ}$., Rio de Janeiro, Vol. 2, pp. 346-355.

Opromolla, D. V. A. and Almeida, S. C. (1965). Primeiros resultados do Tratamento da Lepra com a Kanamicina. Revta Bras. Leprol. 33, 3-21. 
Opromolla, D. V. A. et al. (1965). A terramicina na lepra. Revta Bras. Leprol. 33, 3-21.

Opromolla, D. V. A. and Quagliato, R. (1960). A "Serociclina" na lepra. Observacao em 32 casos. Revta Bras. Leprol. 28, 185-198.

Opromolla, D. V. A. (1972). Contribuicao ao Estudo da Lepra (Hanseniase)-Tese de Doutoramento apresentada à Paculdade de Odontologia de Bauru-Bauru/S.P.

Rees, R. J. W., Pearson, J. M. H. and Waters, M. F. R. (1970). Experimental and clinical studies on rifampicin in treatment of leprosy. $\mathrm{Br}$ med. J. 1, 89-92. J. Christian Med. Ass. India 45,415 .

Shepard, C. C., Levy, L. and Fasal, P. (1972) Rifampicin and M. leprae. In Joint Leprosy Research Conference, $7^{a}$, Tokyo Int J. Lepr. 40, 459-460.

Weinstein, L. (1967). Quimioterapia das doencas microbianas. In As bases farmacológicas da terapeutica. 3rd ed. (Eds L. S. Goodman and A. Gilman) p. 1041. Rio de Janeiro, G.B: Koogan. 